\title{
Egg introduction during complementary feeding according to allergic risk: not just for peanuts!
}

\author{
Elvira Verduci ${ }^{1,2^{*}} \mathbb{D}$, Annamaria Bianchi ${ }^{3}$, Marta Brambilla ${ }^{1,2}$ and Mauro Calvani ${ }^{3}$
}

\begin{abstract}
The relationship between the timing of introduction of complementary foods and later allergy is a topic of current discussion. Although the European Society for Pediatric Gastroenterology Hepatology and Nutrition (ESPGHAN) has recently recommended that potentially allergenic foods may be introduced when complementary feeding is commenced, any time after 4 months, recommendations about egg introduction would be needed mainly for infants with high risk of developing food allergy. Before the first administration in these infants an adequate topical therapy and an evaluation of whole egg-specific lgE serum antibody levels or skin prick tests for egg should be recommended.
\end{abstract}

Keywords: Complementary food, Allergy prevention, Egg allergy

\section{To the Editor,}

Early regular oral egg exposure in infants with eczema prevent later egg allergy. However caution needs to be taken at the first ingestion because many of them have sensitization already by 4 months of age and showed severe reaction.

The term "complementary foods" includes all solid and liquid foods other than breast milk or infant formula. Complementary foods are necessary for both nutritional and developmental reasons and are an important stage in the transition from milk feeding to family foods [1]. There is an important and controversial relationship between the timing of the introduction of complementary foods and later food allergies. Regarding the exposure to potentially allergenic foods, including cows' milk, egg, fish, gluten, peanut, and seeds, international recommendations suggest that there is an increased risk of allergy if solids are introduced before 3 to 4 months, but there is no evidence that delaying the introduction of allergenic foods beyond 4 months reduces the risk of allergy, either for infants in the general population or for those with a family history of atopy [2]. Thus, potentially allergenic foods may be introduced when complementary feeding is commenced any time after

\footnotetext{
* Correspondence: elvira.verduci@unimi.it

${ }^{1}$ Department of Pediatrics, San Paolo Hospital, Milan, Italy

${ }^{2}$ Department of Health Science, University of Milan, Milan, Italy

Full list of author information is available at the end of the article
}

4 months (17 weeks beginning at the 5th month of life), both in breast-fed and formula-fed infants and independently from the risk of atopy, according to the recent updated ESPGHAN recommendation on complementary feeding [1]. Also exclusive or full breast-feeding should be promoted for at least 4 months (17 weeks) and exclusive or predominant breast-feeding for approximately 6 months is considered a desirable goal [1].

In the last decade, prospective interventions have and are studying the hypothesis that the early introduction of potentially allergenic foods can prevent the development of food allergy in the general population or in children with a risk of developing food allergy (atopic dermatitis, atopic familiarity, food sensitization). While for peanuts, a guidance on the timing of the introduction of peanuts stratifying the child's population by the risk of developing allergy has been provided [3], recommendations about egg introduction are lacking in infants at high allergic risk where recommendations would be needed, especially in those countries where the prevalence of egg allergy is certainly greater than that of peanuts. Where the prevention of egg allergy is a concern, the results of 5 interventional trials have been published (STAR [4], STEP [5], HEAP [6], BEAT [7], PETIT [8]) in the last two years. A recent systematic review and meta-analysis [9] concluded that there was moderate evidence from these 5 trials (1915 participants) that egg introduction at 4 to 6 months was associated with reduced egg 
allergy risk (risk ratio [RR] 0.56 [95\% CI $0.36-0.87], \mathrm{I}^{2}=$ $36 \%, P=0.009$ ). However, these systematic review conclusions should be evaluated in the context of limitations in the primary studies, and of the heterogeneity of the included studies. The imprecise effect estimates, issues regarding indirectness, and inconclusive trial sequential analysis findings all need to be taken into account, together with a careful assessment of the safety and acceptability of early egg introduction in different populations. Heterogeneity for egg introduction was due mainly to PETIT study [9]. Indeed in this study small incremental doses of heated egg powder have been administered at 6 to 12 months in infants with atopic dermatitis in association with an aggressive dermatitis control therapy. This approach could justify the interesting results obtained from this study that could have influenced the conclusion of the systematic review. Moreover, studies showed that early introduction at 4-6 months of hen's egg could lead to a large number of allergic reactions, even within the general population. Indeed, four of the trials [4-7] reported allergic reactions (possible even severe) at the ingestion of raw pasteurized egg, due to prior sensitization, ranging from $4.7 \%$ of infants with atopic heredity and skin prick test (SPT) to egg white $<2 \mathrm{~mm}$ [7], to $31 \%$ of the infants affected by moderate-severe atopic dermatitis [4]. Otherwise in the PETIT study no infant withdrew because of adverse reactions caused by the trial powder, even though this study enrolled high-risk infants with atopic dermatitis. However, in this trial, a very low daily dose of heated egg powder was introduced orally at 6 months ( $25 \mathrm{mg}$ of egg protein which is equivalent to $0.2 \mathrm{~g}$ of egg). Therefore the quantity of allergen and the degree of cooking seem to influence the probability of an allergic reaction, even at the first ingestions of egg.

From a practical point of view, the dose administered in the PETIT study is not easy to replicate given that egg is not commonly eaten in powder form. Indeed, considering that a medium sized egg weighs about $60 \mathrm{~g}$, and that the edible part is about $50 \mathrm{~g}$, a $1 / 250$ th of an egg should be administered to give $0.2 \mathrm{~g}$ of egg (or $25 \mathrm{mg}$ of protein)!

In conclusion, while waiting for other studies to clarify the preventive effect and the safety of an early introduction of heated egg, some indications about egg introduction during complementary feeding according to allergic risk can be provided based on existing recommendations for other highly allergenic nutrients. When the introduction of egg to infants at very high-risk (with moderate-severe atopic dermatitis) is considered, it seems reasonable to adopt a behavior similar to that proposed for peanuts (Fig. 1). In these

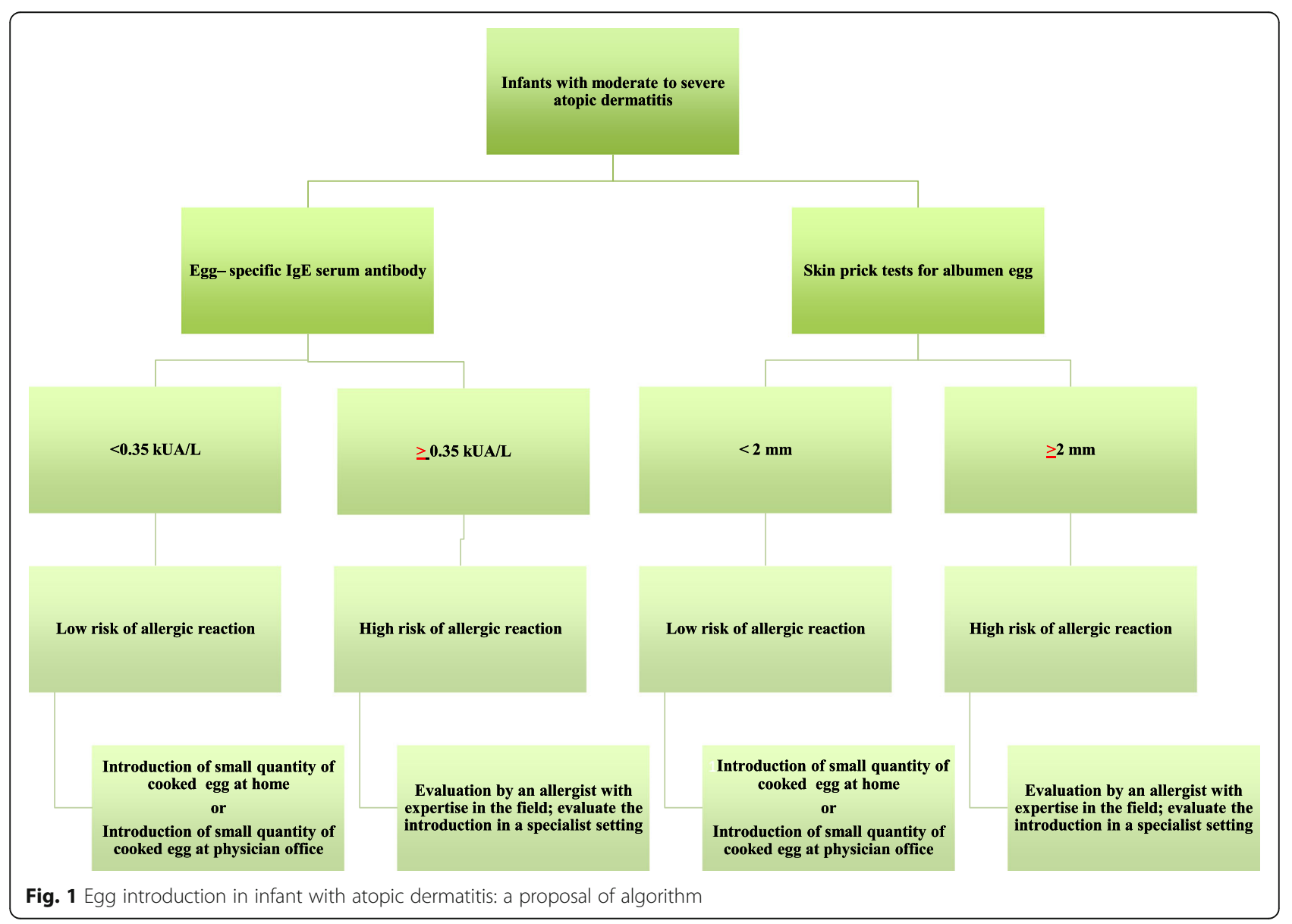


infants an adequate topical therapy should be recommended, as well as evaluation of whole egg-specific IgE serum antibody levels or performing skin prick tests for egg before the first administration. Other tests, e.g. patch test, are not useful [10]. If skin prick test or sIgE are negative, cooked egg can be introduced at low quantity when complementary feeding is commenced. This, because in two trials that enrolled un-sensitized infants, with egg white extract SPT $<2 \mathrm{~mm}$ [6] or hen's egg $\operatorname{sIgE}<0.35 \mathrm{kU}_{\mathrm{A}} / \mathrm{L}$ [7] the introduction of raw hen's egg (un-cooked) at between 4 and 6 months, induced mild or moderate reactions. If skin prick test or sIgE are positive, egg must be introduced in a specialized setting with emergency support immediately available and under the supervision of an allergist with expertise in this field.

\section{Abbreviation}

SPT: skin prick test

\section{Funding}

Department of Health Science, San Paolo Hospital, University of Milan.

\section{Authors' contributions}

$\mathrm{AM}$ and $\mathrm{MC}$ analyzed and interpreted the previous collected data regarding complementary feeding and allergic diseases. EV and MB were the major contributor in writing and revising the manuscript. All authors read and approved the final manuscript.

\section{Ethics approval and consent to participate}

Not applicable.

\section{Consent for publication}

Not applicable.

\section{Competing interests}

The authors declare that they have no competing interests.

\section{Publisher's Note}

Springer Nature remains neutral with regard to jurisdictional claims in published maps and institutional affiliations.

\section{Author details}

'Department of Pediatrics, San Paolo Hospital, Milan, Italy. ${ }^{2}$ Department of Health Science, University of Milan, Milan, Italy. ${ }^{3}$ Department of Pediatrics, S. Camillo-Forlanini Hospital, Rome, Italy.

Received: 12 March 2018 Accepted: 2 July 2018

Published online: 06 July 2018

\section{References}

1. Fewtrell M, Bronsky J, Campoy C, Domellöf M, Embleton N, Fidler Mis N, Hojsak I, Hulst JM, Indrio F, Lapillonne A, Molgaard C. Complementary feeding: a position paper by the European Society for Paediatric Gastroenterology, hepatology, and nutrition (ESPGHAN) committee on nutrition. JPGN. 2017;64: 119-32. https://doi.org/10.1097/MPG.0000000000001454.

2. Muraro A, Halken S, Arshad SH, Beyer K, Dubois AE, Du Toit G, et al. EAACl food allergy and anaphylaxis guidelines group. EAACI food allergy and anaphylaxis guidelines. Primary prevention of food allergy. Allergy. 2014;69: 590-60. https://doi.org/10.1111/all.12398.

3. Togias A, Cooper SF, Acebal ML. Assa'ad a, baker JR Jr, Beck LA, et al. addendum guidelines for the prevention of peanut allergy in the United States: report of the National Institute of Allergy and Infectious Diseasessponsored expert panel. Ann Allergy Asthma Immunol. 2017;118:166-73. https://doi.org/10.1016/j.pedn.2016.12.006.
4. Palmer DJ, Metcalf J, Makrides M, Gold MS, West CE, et al. Early regular egg exposure in infants with eczema: a randomized controlled trial. J Allergy Clin Immunol. 2013;132:387-92. https://doi.org/10.1016/j.jaci.2013.05.002.

5. Palmer DJ, Sullivan TR, Gold MS, et al. Randomized controlled trial of early regular egg intake to prevent egg allergy. J Allergy Clin Immunol. 2017;139: 1600-7. https://doi.org/10.1016/j.jaci.2016.06.052

6. Bellach J, Schwarz V, Ahrens B, Trendelenburg V, Aksunger O, Kalb B, et al. Randomized placebo-controlled trial of hen's egg consumption for primary prevention in infants. J Allergy Clin Immunol. 2017;139:1591-9. https://doi.org/10.1016/j.jaci.2016.06.045.

7. Wei-Liang Tan J, Valerio C, Barnes EH, Turner PJ, Van Asperen PA, Kakakios $A M$, et al. A randomized trial of egg introduction from 4 months of age in infants at risk for egg allergy. J Allergy Clin Immunol. 2017;139:1621-8. https://doi.org/10.1016/j.jaci.2016.08.035.

8. Natsume O, Kabashima S, Nakasato J, Yarnamoto-Hamada K, Narita M, Konodo M, et al. Two-step egg introduction for prevention of egg allergy in high-risk infants with eczema (PETIT): a randomised, double-blind, placebocontrolled trial. Lancet. 2017;389(10066):276-86. https://doi.org/10.1016/ S0140-6736(16)31418-0.

9. lerodiakonou D, Garcia-Larsen V, Logan A, Groorne A, Cunha S, Chivinge J, et al. Timing of allergenic food introduction to the infant diet and risk of allergic or autoimmune disease. A systematic review and meta-analysis. JAMA. 2016;316:1181-92. https://doi.org/10.1001/jama.2016.12623.

10. Caglayan Sozmen S, Povesi Dascola C, Gioia E, Mastrorilli C, Rizzuti L, Caffarelli C. Diagnostic accuracy of patch test in children with food allergy. Pediatr Allergy Immunol. 2015;26:416-22. https://doi.org/10.1111/pai.12377.

\section{Ready to submit your research? Choose BMC and benefit from:}

- fast, convenient online submission

- thorough peer review by experienced researchers in your field

- rapid publication on acceptance

- support for research data, including large and complex data types

- gold Open Access which fosters wider collaboration and increased citations

- maximum visibility for your research: over $100 \mathrm{M}$ website views per year

At BMC, research is always in progress.

Learn more biomedcentral.com/submissions 